\title{
Erosion problems of shore line and counter measurement by various geomaterials
}

\author{
Eun Chul Shin ${ }^{1}$, Sung Hwan Kim ${ }^{1, *}$, and Abdul $\mathrm{Hakam}^{2}$, and Bambang Istijono ${ }^{2}$ \\ ${ }^{1}$ Incheon National University, Songdo-dong, 119, Academy-ro, Yeonsu-gu, Incheon, 22012, Republic \\ of Korea \\ ${ }^{2}$ Andalas University, Limau Manis, Pauh, Kota Padang, Sumatera Barat 25163, Indonesia
}

\begin{abstract}
Coastal regions are vulnerable to erosion and depletion of land areas for human habitation and economic activities. A description of various types of the hydraulic structures associated in erosion protection applications are provided. Recently, because of the shortage of natural rock, traditional forms of river and coastal structures have become very expensive to build and maintain. Therefore, the materials used in hydraulic and coastal structures are changing from the traditional rubble and concrete systems to the cheaper materials and systems. Erosion problems in coastal zones are become increasingly serious due to the development of artificial activities related to the expansion of city functions, industrial complexes and harbour facilities, as well as the removal of sea sand for use in aggregate resources at the construction sites, which is a major factor in the inflow and outflow of sea sand. In addition, the environmental and economical importance of the coastal beach zones is increased. However, coastal beach zones are constantly eroded by waves accompanied with the rising water level due to storm surges, hurricanes, winter storm impact, and high tide. This erosion motion accelerates the regression of the coastal cliff due to the regression of the dunes or the shoreline. In addition, the regression leads to loss of real estate in the hinterland and ruins the shock-absorbing zone between land and sea. The application benefits for erosion protection are discussed. Several case studies are included.
\end{abstract}

\section{Introduction}

The materials used in hydraulic and coastal structures are changing from traditional rubble and concrete to the environmental materials. This material is used to construct coastal and shore protection structures, such as embankments, groins, jetties, detached breakwaters and so on. Marine and other hydraulic environments are susceptible to erosion, which is caused by the action of waves, tides, currents and other water motion. The consequence of erosion can range from a simple loss of surface soil to the wholesale undermining and collapse of structures. To prevent erosion from occurring a variety of preventative measures are used to reduce the water forces acting on susceptible structures. Generally these measures fall into one of three categories:

\footnotetext{
* Corresponding author: sherikim315@naver.com
} 
- Geometrical measures, where the shape of the structure is altered in order to reduce the water forces below a minimum threshold.

- Stabilization measures, where the exposed structure is protected from erosion by stabilizing the susceptible soil. Examples include the provision of revetments, etc.

- External measures, where exposed structure is protected from erosion by the provision of a protective structure, placed at some distance. Examples include dykes and breakwaters, etc.

\section{Marine structures}

\subsection{Revetments}

The title is set in bold 16-point Arial, justified. The first letter of the title should be capitalised with the rest in lower case. You should leave $22 \mathrm{~mm}$ of space above the title and $6 \mathrm{~mm}$ after the title. A revetment is a protective surface capable of withstanding hydraulic forces that would otherwise cause erosion to the soil or structure it covers beneath. A revetment generally consists of an armour layer that directly resists hydraulic forces but would usually include sub-layers of bridging armour and filter layers. The armour layers may be constructed of rocks, concrete units, etc. The filter layers are traditionally graded granular materials.

These types of layers are ideal materials for erosion protection because they can be installed in a range of sizes; they are flexible and thus can conform to the underlying soil surface; and they are highly permeable which enables pore water pressures to be dissipated rapidly. Geotextiles have rapidly and virtually replaced the use of graded granular filters for cost, engineering effectiveness, installation expediency and other reasons.

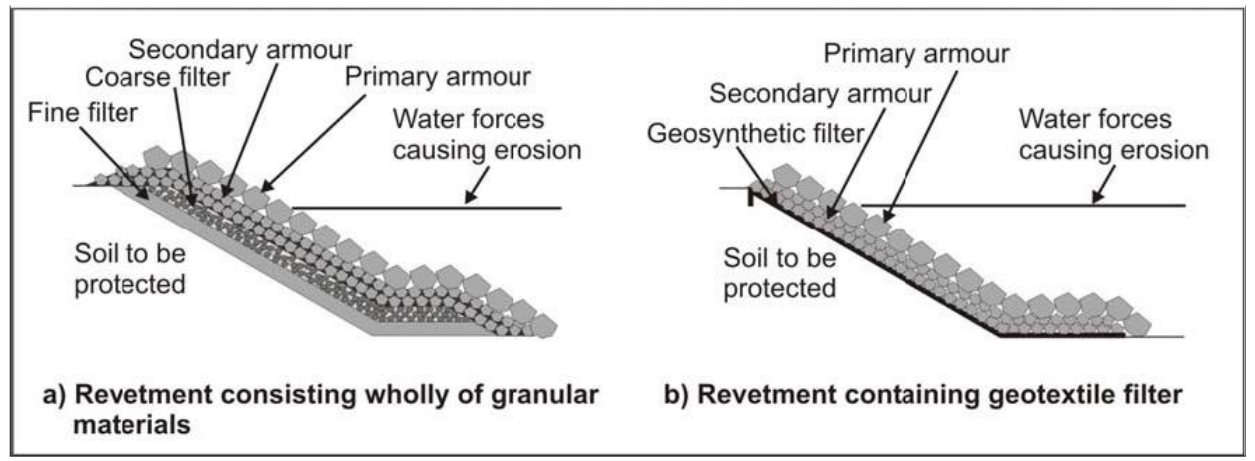

Fig. 1 Rock Armour Revetment with and without Geotextile.

\subsection{Dykes and Breakwaters}

Dykes and breakwaters are generally broad based hydraulic structures with side slopes sloping away on either side of the crest. Dykes are typically for containment while breakwaters are designed to moderate the wave climate reaching a specific area to be protected from erosion. There are various types of dykes and breakwaters but by far the most common is the rubble mound type, formed by dumping of rocks (see Fig. 2). When rubble mound dykes are used for reclamation purposes, a filter layer (usually a filter geotextile) is placed between the dyke and the soil infill. Other structures may have a core of finer granular material, which would require a revetment protection cover. A basal geotextile layer is commonly used in the construction of dykes and breakwaters when the foundation is loose sand, silt or soft clay either as a separator, filter or reinforcement or combination thereof. 


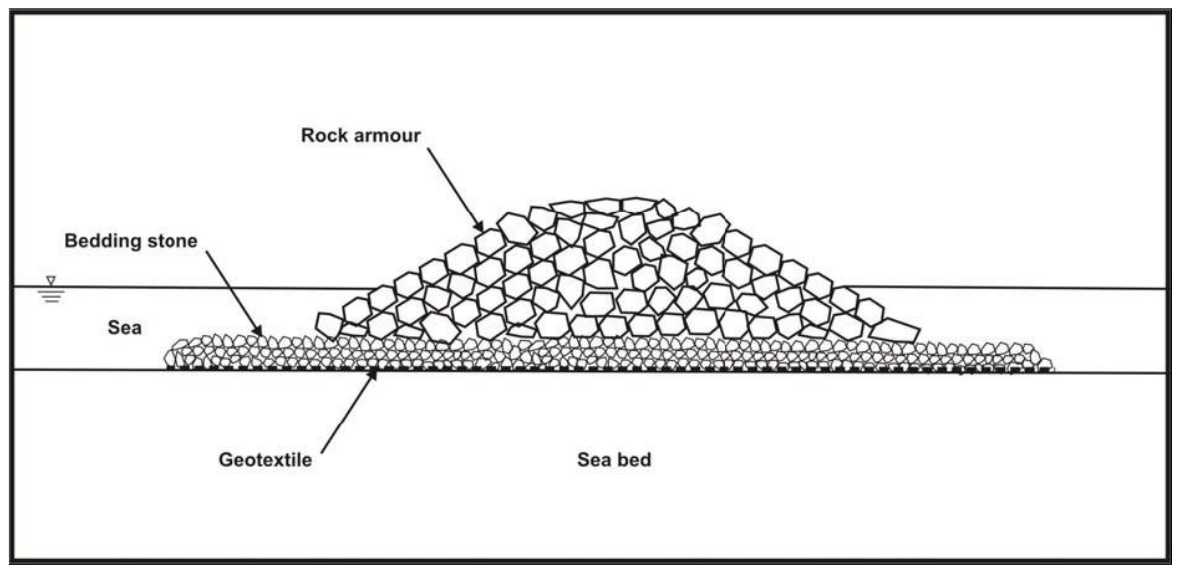

Fig. 2. Conventional Rubble Mound Dyke and Breakwater in Padang Indonesia.

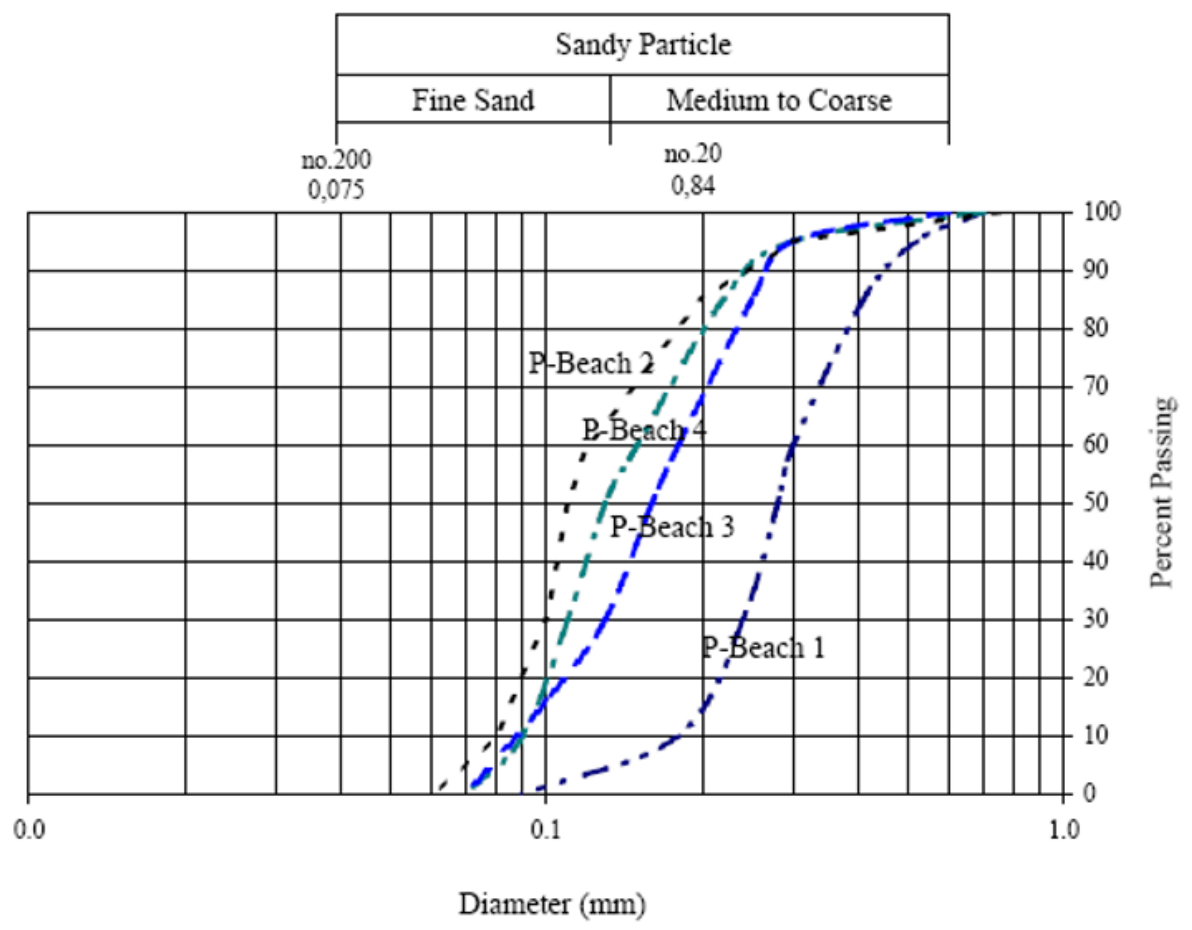

Fig. 3. Sieve Analyses of Padang Beach. 


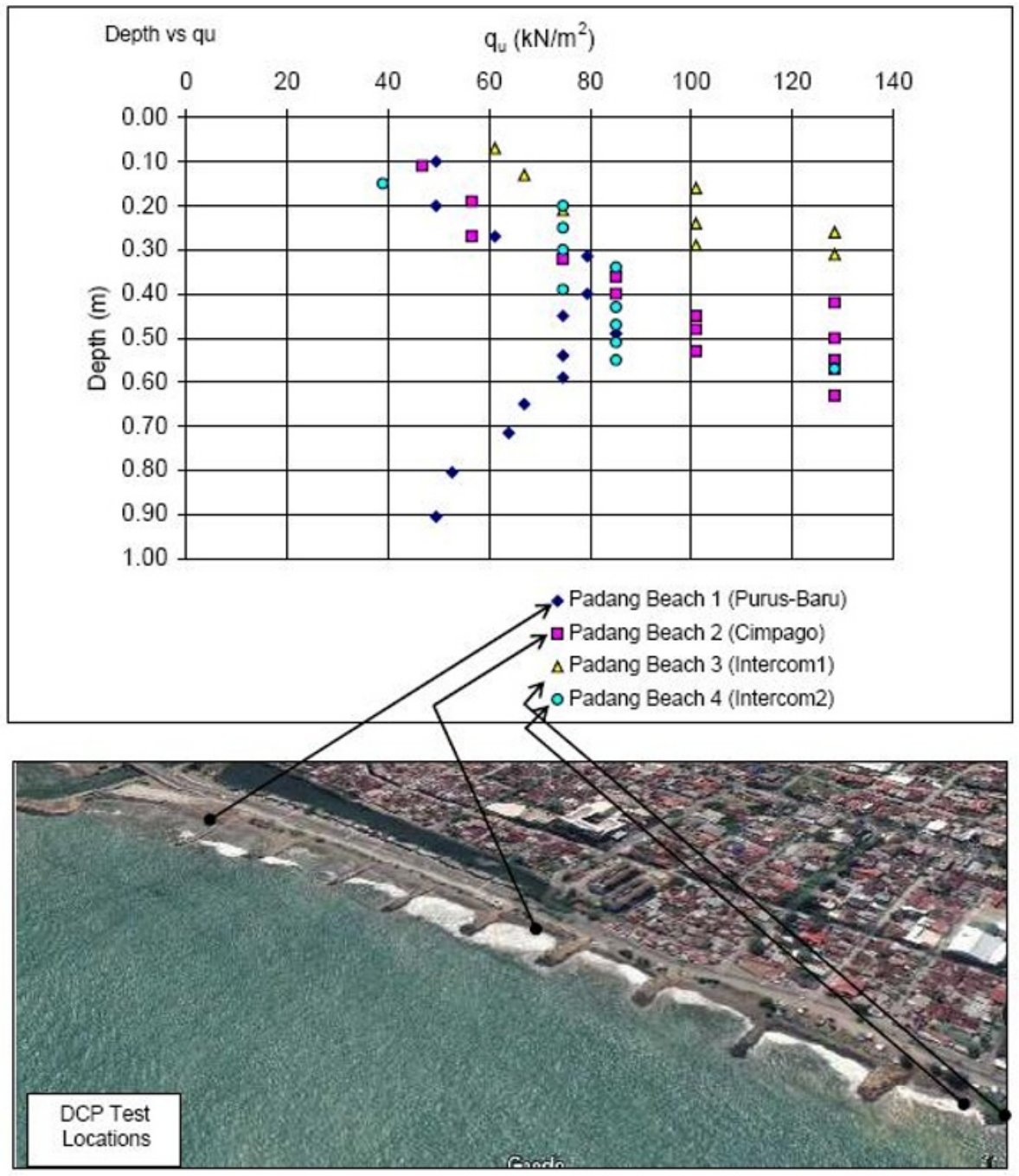

Fig. 4. Bearing Capacity test using Dynamic Cone Penetration (DCP) Test.

\section{Case studies}

\subsection{Geotextile tubes as submerged dykes for shoreline management in Malaysia}

The Malaysian shoreline is in excess of $4800 \mathrm{~km}$ and a large portion of this comprise of sandy coasts. Sandy shorelines dominate the east coasts of Peninsular Malaysia and occupy a significant portion of the coasts of Sabah and Sarawak. The Economic Planning Unit (1985) reported that about $30 \%$ of the Malaysian shoreline suffers from erosion, with a high percentage of the eroded areas largely along the shoreline of Peninsular Malaysia. Development of coastal areas to serve important economic and social needs often interferes with natural processes to the extent of causing the shoreline to respond differently and to alter the erosion and accretion patterns. Erosion of coastal lands in Malaysia has reached an alarming stage and the number of problem sites has increased over the last 12 years. The 
consequences of coastal erosion are severe in Malaysia as much of the economic and social life of Malaysia depends on activities in its coastal areas. Many of these activities are served by facilities that have either already been damaged or will be damaged in the near future. The affected activities include agricultural community life, recreation, transportation and tourism. World wide climatic changes have resulted in significantly increased incidences of shoreline erosion and effective control measures are necessary to protect these shorelines.

Teluk Kalong in the district of Kemaman in Terengganu, Malaysia has encountered erosion of the shoreline. A case study of the shoreline protection measure in a pilot project at Teluk Kalong is discussed. Pantai Batu Buruk is located in Kuala Terengganu, the capital city of the state of Terengganu in Malaysia. The shoreline is exposed to the direct impacts of severe storms, especially during the North-East Monsoon periods, causing widespread erosion. The result of the continuous erosion had created a sandy beach which, however, is not conducive to beach users, particularly with the steepened beach profile. The second case study in this paper describes the shoreline protection measures at this beach front and the results of preliminary performance assessments carried out.

Structural control measures have been employed in the past throughout Malaysia. The measures used are generally designed to harden and armour selected areas against wave attack as well as the use of groynes to trap sediments and alter long-shore transport. These include rock revetments, concrete-faced bunds and dykes, and rock-filled or concrete groyne structures. The erosion problems in Malaysia have resulted in the construction of over $60 \mathrm{~km}$ of revetments. Even with this effort, continuous erosion still persists, paving the way for a search of alternative forms of protection.

The function of the revetment structure is to prevent the loss of shore sediment and to limit wave run-up from overtopping the structure. Wave run-up is reduced by the roughness of the revetment surface and the size of the rocks is determined by wave height. Soil bearing capacity will determine the strength of the foundation support of the structure. Commonly, a layer of geotextile is incorporated into the revetment structure as a filter and separator. Common causes of failure to these hard structural measures are undermining of toe, excessive settlement, failure due to lateral movement, overtopping and flanking. Failure of filter system will also result in excessive loss of materials behind the structure and may result in excessive settlement

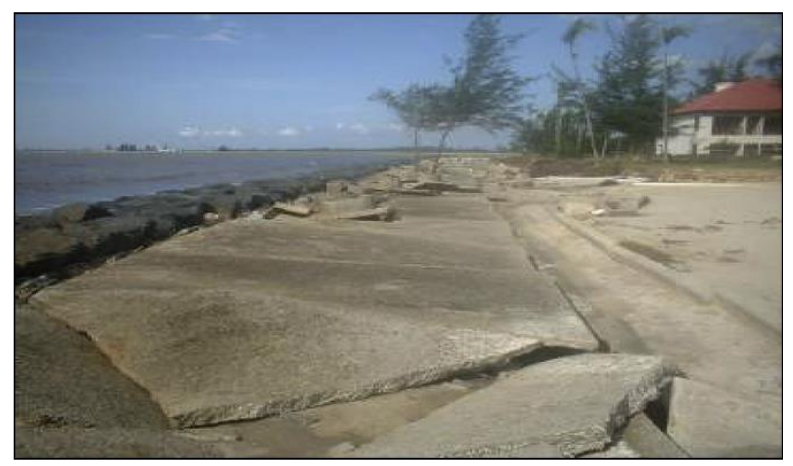

Fig. 5. Concrete units used for erosion protection. 


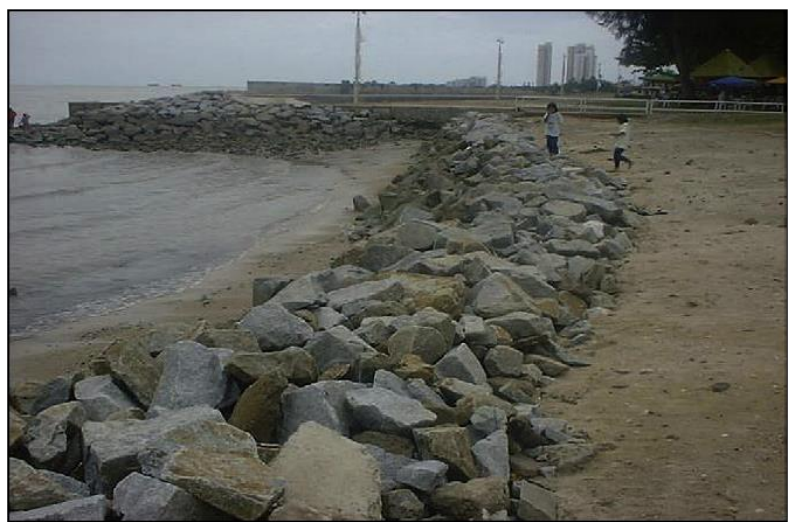

Fig. 6. Rock revetment used for erosion.

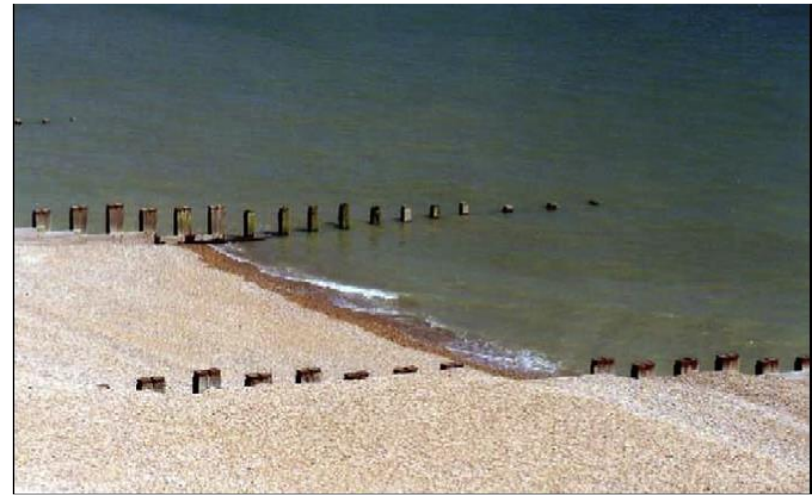

Fig. 7. Concrete groyne structures protection.

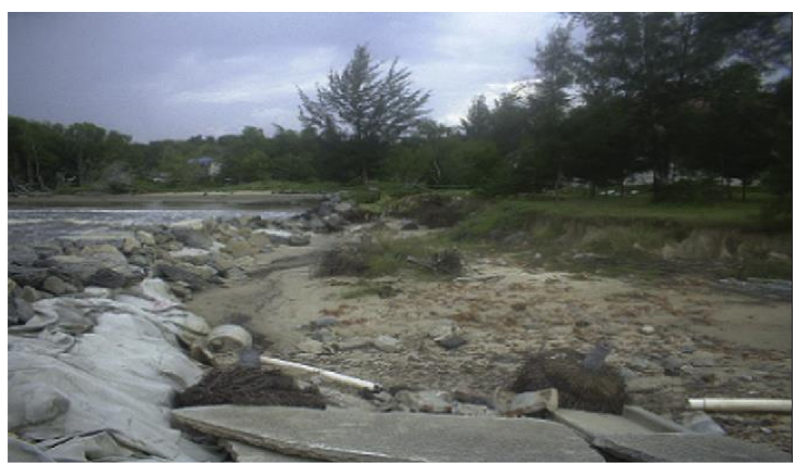

Fig. 8. Failure of protection measure protection.

\subsection{Case study no. 1: pilot project at Teluk Kalong, Kemaman, Terengganu}

The shoreline along the coast of Teluk Kalong is composed mainly of granular sandy materials. These sediments are easily erodible when subjected to wave forces and if not adequately protected. A length of about $500 \mathrm{~m}$ in length of this existing shoreline had been exposed to severe erosion, resulting in instability of the existing seawall, which consisted of precast concrete slabs. The severity of the shoreline erosion and the strength of the waves approaching the shoreline. Loss of sandy materials behind the concrete panels due to severe 
erosion had resulted in large and uneven settlements of the panels. The condition of the beach front was also not suitable for recreational activities due to the rather narrow and steep foreshore area. A pilot project was initiated in 2006 by the Public Works Department to remedy the situation by using the geotextile tube as a submerged dyke. The design concept for the coastal erosion protection and beach enhancement is to use a system of geotextile tubes sitting over a layer of apron mattress. The inner structure of these geotextile tubes consists of high strength woven polypropylene geotextile with ultimate tensile strengths of $150 \mathrm{kN} / \mathrm{m}$ in warp and weft directions. An outer layer of nonwoven polypropylene geotextile having ultimate tensile strength of $40 \mathrm{kN} / \mathrm{m}$ in machine and cross-machine directions was stitched onto the inner reinforcement layer, to increase the durability of the tube due to abrasion and ultra-violet degradation. The fabrics are all tested for compliance to high seam strengths in excess of $80 \%$ of the ultimate tensile strength. These geotextile tubes were installed for a total length of $500 \mathrm{~m}$ along the beach front. The design requirements adopted for the development of the system included: (a) The geotextile tubes are to be sited at approximately $150 \mathrm{~m}$ from the shoreline, (b). The geotextile tubes shall be totally submerged at low tide condition, with a freeboard of $1 \mathrm{~m}$.

Coast is a highly dynamic environment. Formation of coast is affected by many factors such as natural, biological and chemical processes as well as human activities (Cui et al., 2015). The anthropogenic activities such as sand mining, construction of ports and harbors, agriculture and aquaculture industries have contributed to sediment deficit along the coastlines. Although increases in population, construction activity and deforestation could contribute to socio-economy development, the coastline erosion is accelerated as well inevitably (Anfuso and Pozo, 2009).

\section{Conclusions}

According to the Malaysia's National Coastal Erosion Report, $29 \%$ of the 4,809 km coastlines in Malaysia are experiencing coastline degradation. Muddy coasts are commonly found along the west coast of Peninsular Malaysia. Issues such as mangrove depletion and shoreline erosion have been noticed since the 1980's. Some of the highly eroded coastal areas in Peninsular Malaysia are shown in Fig. 9.

Muddy coasts and mangroves ecosystems are commonly found along the west coast of Peninsular Malaysia. Mangroves function as natural barrier to protect the muddy coastline from wave impacts. However, the amount of mangrove had been decreasing since the past decades due to natural and anthropogenic factors. In parallel to the loss of mangrove belts, muddy coastline experiences severe erosion thereafter.

Conventional mitigation measures such as construction of concrete revetments and sand dunes have been carried out by local authorities. These methods are able to prevent further erosion of coastline; however, they do not promote natural sediment nourishment. Construction of concrete breakwaters on mudflat is less typical in Malaysia due to higher cost and complicated construction procedures. For instance, the construction of $80 \mathrm{~m}$ long Lblock concrete breakwaters in SHD (Fig. 8) would take about two months to complete. The complicated procedures include design and precast of L-block concrete units, transportation of equipment and materials to site, site clearing, transfer items onto the deformable mudflat, arrangement of concrete units and so on. The total cost for the pilot project and maintenance is about USD 26,000 for the $80 \mathrm{~m}$ long concrete breakwaters. The cost is inclusive of precast L-block units, gabion baskets, stone, 8 workers and mangroves planting (Kamali et al., 2010). The cost of L-block concrete breakwaters is high mainly due to the manpower and long construction time frame. Geotube breakwaters are more attractive for muddy coastline protection as compared to the typical concrete structures due to the ease of installation. The lighter weight of geotube units facilitates transportation to site and handling. Moreover, 
filling of the geotube unit requires only simple equipment and skilled workers are not required. Shin and Oh (2007) described the quick geotube filling procedures which was completed in approximately one hour. Hence, the installation cost of geotube breakwater is cheaper as compared to concrete breakwater. In year 2014, installation of $100 \mathrm{~m}$ long geotube breakwaters costs approximately MYR 90,000. The longer the total length of geotube breakwaters, the lower the cost. This is because the project cost is dominated by machineries, site cleaning works and workers, instead of geotube and filling materials. Comparatively, Lblock concrete breakwaters installed in SHD costs about MYR 140,000 for a coverage of 80 $\mathrm{m}$. Although geotube breakwaters are feasible for the application in muddy coastal area, the structure has its own limitations. For example, geotube breakwaters are more fragile as compared to concrete breakwaters. Geotube can be damaged by sharp items and losses its function as breakwater after spillage of filling materials. Besides that, single-line geotube breakwaters are not able to withstand the impact of high waves. Therefore, single-line geotube breakwaters are more suitable to be applied as coastal erosion protection structures in coastal area (e.g. SHD) with smaller hydrodynamic forces.

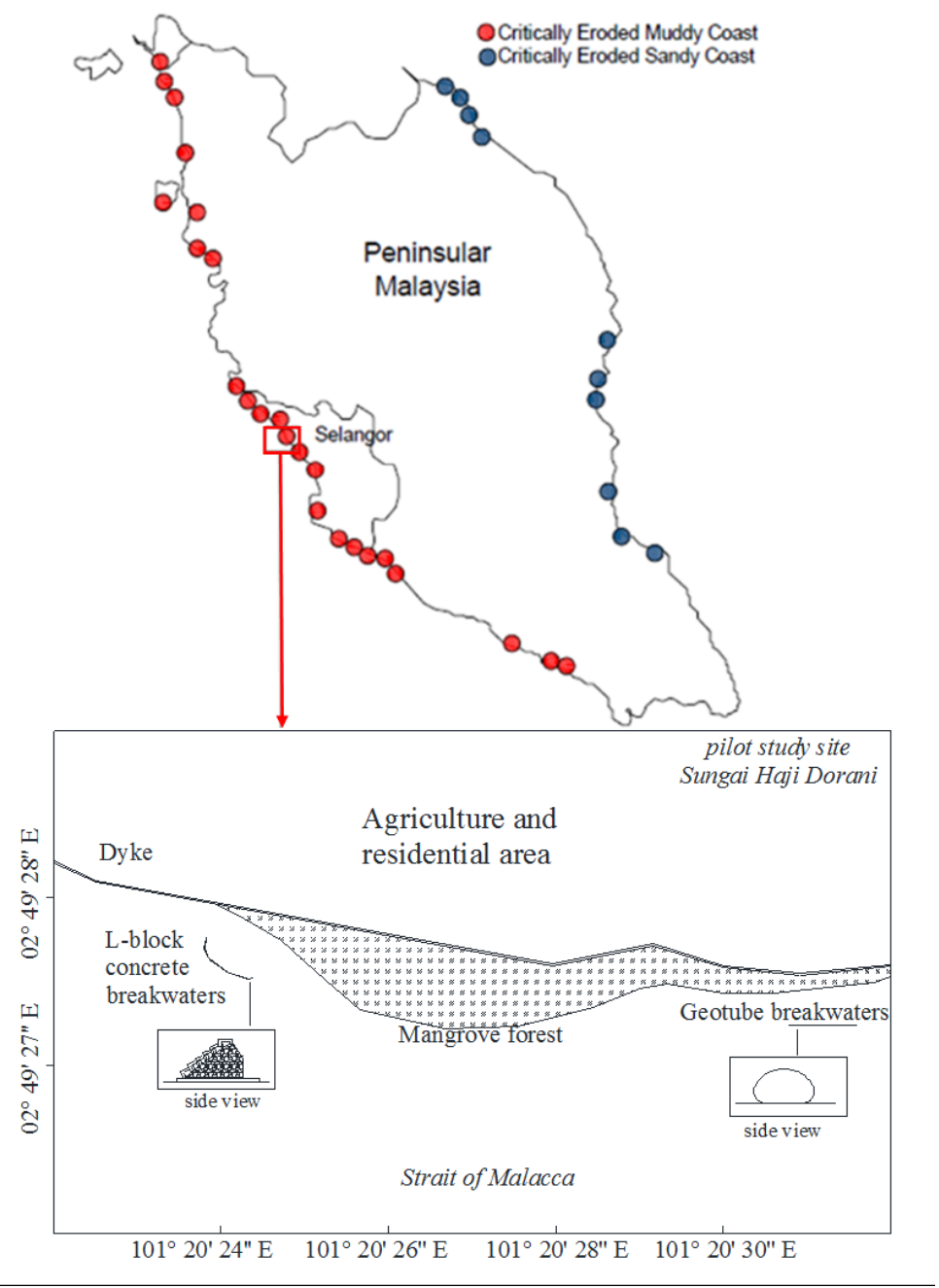

Fig. 9. Critical eroded coasts in Peninsular Malaysia and location of pilot study site. 


\section{References}

1. ASTM D1117. Standard Guide for Evaluating Nonwoven Fabrics (American Society for Testing and Materials, Philadelphia, 2001)

2. R.J. Barrett, Use of Plastic Filters in Coastal Structures, Proceedings 16th International Conference on Coastal Engineering, 1048-1067 (1966)

3. H. Den Adel, C.S.H. Hendrikse, K.W. Pilarczyk, Design and Application of Geotubes and Geocontainers, Proceedings 1st European Conference on Geosynthetics: Applications, Design and Construction, 925-931 (1996)

4. A.R. Horrocks, S.C. Anand, Handbook of Technical Textiles (Woodhead, Cambridge, 2000)

5. R.A. Jewell, Soil Reinforcement with Geotextiles, Construction Industry Information Association (Thomas Telford, London, 1996)

6. R.M. Koerner, Designing with Geosynthetics, Fourth Edition (Prentice Hall, New Jersey, 1999)

7. C.R. Lawson, Geotextiles and Geomembranes Journal 11, 431-448 (1992)

8. K.W. Pilarczyk, Geosynthetics and Geosystems in Hydraulic and Coastal Engineering (Balkema, Rotterdam, 2000)

9. K.W. Pilarczyk, R.B. Zeidler, Offshore Breakwaters and Shore Evolution Control (Balkema, Rotterdam, 1986)

10. K.W. Pilarczyk, M.K. Breteler, T. Stoutjesdijk, Stability Criteria for Geosystems - An Overview, Proceedings 6th International Conference on Geosynthetics, 1165-1172 (1998)

11. T.W. Yee, Construction of Underwater Dykes using Geotextile Containment Systems, Proceedings 7th International Conference on Geosynthetics 3, 1161-1164 (2002)

12. T.W. Yee, Elsevier 3-28, 817-832 (2005)

13. E.C. Shin, J.K. Kang, Y.I. Oh, Proceedings of the 17th International Conference on Soil Mechanics and Geotechnical Engineering, IOS Press, 1546-1549 (2000)

14. E.C. Shin, Journals of Korean Geoenvironmental Society 7-6, 13-22 (2006)

15. E.C. Shin, Y.I. Oh, Journal of Geotechnical Engineering Conference, Korean Geotechnical Society, 549-556 (2002)

16. E.C. Shin, Y.I. Oh, Journal of the Spring Geotechnical Engineering Conference, Korean Geotechnical Society, 504 -511 (2000)

17. E.C. Shin, Y.I. Oh, J.K. Kang, S.H. Kim, Proceedings of Korean Geosynthetics Society, 127-137 (2007) 